EVALUASI, 3(2), September 2019, ISSN 2580-3387 (print) |

ISSN 2615-2886 (online)

Homepage : http://e-journal.staima-alhikam.ac.id/index.php/evaluasi

DOI : : http://doi.org/10.32478/evaluasi.v3i2.265

Article type : Original Research Article

\title{
PENGARUH KEPEMIMPINAN TERHADAP PRESTASI KERJA KARYAWAN DI MADRASAH MU'ALLIMIN MU'ALLIMAT PONDOK PESANTREN SUNAN DRAJAT LAMONGAN
}

\author{
Miftachul Ulum, Abdul Mun'im, Muslih \\ Institut Pesantren Sunan Drajat Lamongan \\ JI. Pon. Pes. Sunan Drajat Banjarwati Paciran Lamongan
}

\begin{abstract}
Leadership plays a very important role in the overall effort to improve work performance. In this study raises a problem that occurs, namely how much influence the leadership on employee performance at the Mu'allimin Mu'allimat Madrasah Sunan Drajat Lamongan Islamic Boarding School? From the problems raised, we aim to measure. We want to measure how much influence leadership has on employee performance at the Mu'allimin Mu'allimat Madrasah Sunan Drajat Lamongan Islamic Boarding School. This research is a type of survey research on all employees and teachers who work in the Mu'allimin Mu'alimat Madrasa Sunan Drajat Banjarwati, amounting to 45 people. The results of the analysis show a correlation (R) of 0.448 with an opportunity for error $(p)$ of 0,000 . while the effective contribution of leadership to work performance can be seen from the Determination coefficient (R2) of 0.201, which means that the contribution of leadership variables to work performance is only $20.1 \%$, the remaining $79.9 \%$ indicates the possibility of other factors that affect the work performance of your Madrasah employees' allimin Mu'alimat Sunan Drajat
\end{abstract}

Keywords : Leadership Style; Work performance; Teacher

Abstrak: Kepemimpinan memainkan peranan yang sangat penting dalam keseluruhan upaya untuk meningkatkan prestasi kerja. Pada penelitian ini memunculkan suatu permasalahan yang terjadi yaitu seberapa besar pengaruh kepemimpinan terhadap prestasi kerja karyawan Di Madrasah

Email address: drajatulum@insud.ac.id,munimdrajat@gmail.com, muslich23@gmail.com

EVALUASI: Jurnal Manajemen Pendidikan is licensed under

The CC BY License (https://creativecommons.org/licenses/by-sa/4.0/) 
Mu'allimin Mu'allimat Pondok Pesantren Sunan Drajat Lamongan ?. Dari permasalahan yang diajukan maka kami bertujuan ingin mengukur Kami ingin mengukur seberapa besar pengaruh kepemimpinan terhadap prestasi kerja karyawan Di Madrasah Mu'allimin Mu'allimat Pondok Pesantren Sunan Drajat Lamongan. Penelitian ini merupakan jenis penelitian survey terhadap semua karyawan dan guru yang bekerja di Madrasah Mu'allimin Mu'alimat Sunan Drajat Banjarwati yaitu berjumlah 45 orang.. Hasil analisis menunjukkan korelasi $(R)$ sebesar 0.448 dengan peluang galat $(p)$ sebesar 0,000 . sedangkan sumbangan efektif kepemimpinan terhadap prestasi kerja dapat dilihat dari koefisien Determinasi $\left(R^{2}\right)$ sebesar 0.201 yang berarti sumbangan variabel kepemimpinan terhadap prestasi kerja hanya sebesar 20,1 \% selebihnya 79,9 \% mengindikasikan adanya kemungkinan faktor lain yang mempengaruhi prestasi kerja pada karyawan Madrasah Mu'allimin Mu'alimat Sunan Drajat

Keywords : Gaya Kepemimpinan; Prestasi Kerja; Tenaga Pendidik

\section{A. PENDAHULUAN}

Perkembangan dunia usaha ini sudah berkembang pesat apalagi dalam dunia millenial atau era 4.0 baik dibidang industri, dagang maupun jasa, telah menmbulkan berbagai macam permasalahan yang dihadapi dan harus di pecahkan oleh manajemen. Dalam hal ini manajemen dituntut mampu mengelola serta menjalankan perusahaan seefektif dan seefisien mungkin agar dapat bertahan dalam persaingan dunia usaha, lebih-lebih dalam menghadapi era pasar bebas saat ini.Salah satu faktor penentu keberhasilan perusahaan adalah manusia.bahkan manusia memberikan kontribusi terbesar atau menjadi ujung tombak bagi keberhasilan perusahaan dibandingkan faktor lain seperti modal, bahan baku atau mesin. Faktor kepemimpinan memainkan peranan yang sangat penting dalam keseluruhan upaya untuk meningkatkan kinerja, baik pada tingkat kelompok maupun pada tingkat organisasi. Dikatakan demikian karena kinerja tidak hanya menyoroti pada sudut tenaga pelaksana yang pada umumnya bersifat teknis akan tetapi juga dari kelompok kerja dan manajerial ${ }^{1}$

Penelitian lapangan ini menggabarkan suatu permasalahan antara kepemimpinan dan prestasi kerja yang terjadi di lembaga pendidikan. Dalam

${ }^{1}$ Biatna Dulbert Tampubolon, “Analisa Faktor Gaya Kepemimpinan Dan Faktor Etos Kerja Terhadap Kinerja Pegawai Pada Organisasi Yang Telah Menerapkan SNI 199001-2001," Jurnal Standardisasi 9, no. 3 (2007): 106-15. 
EVALUASI, 3(2), September 2019, ISSN 2580-3387 (print) |

ISSN 2615-2886 (online)

http://doi.org/10.32478/evaluasi.v3i2.265

penelitian ini kami rangkai suatu permasalahan yang terjadi yaitu seberapa besar pengaruh kepemimpinan terhadap prestasi kerja karyawan Di Madrasah Mu'allimin Mu'allimat Pondok Pesantren Sunan Drajat Lamongan ?. Dari permasalahan yang diajukan maka kami bertujuan ingin mengukur Kami ingin mengukur seberapa besar pengaruh kepemimpinan terhadap prestasi kerja karyawan Di Madrasah Mu'allimin Mu'allimat Pondok Pesantren Sunan Drajat Lamongan.

Apabila pimpinan perusahaan menginginkan keberhasilan usahanya, maka sumber daya manusia (SDM) harus dibina, dikoordinasikan dan diarahkan sesuai dengan tujuan perusahaan yang akan dicapai serta adanya kepuasan pada diri karyawan. Sumber daya manusia bukanlah faktor produksi seperti mesin dan bahan baku melainkan merupakan "partner" kerja bagi organisasi. Tenaga yang tersedia bagi perusahaan tidak semuanya dapat langsung menjadi tenaga kerja yang produktif. Tenaga kerja dalam perusahaan harus diseleksi, ditempatkan, dilatih, dinilai prestasinya serta diberikan kontra prestasi yang memadai, sehingga prestasi kerja dapat terus ditingkatkan dan perusahaan dapat mencapai tujuan yang diinginkan.

Perusahaan yang menyadari pentingnya meningkatkan prestasi karyawan, akan selalu memperhatikan faktor-faktor apa saja yang dapat mempengaruhi prestasi kerja karyawan. Diantara faktor-faktor yang mempengaruhi prestasi kerja karyawan adalah kepemimpinan yang baik dan cocok dengan situasi dan kondisi dalam organisasi yang lebih banyak di tentukan oleh keahlian seorang pimpinan dalam menggerakkan orang lain untuk berprestasi yaitu yang disebut ketrampilan manajerial (Managerial Skill) daripada ketrampilan teknis (Technical skill) yang dimilikinya, sehingga akan menimbulkan rasa senang pada karyawan dan rasa senang ini akan akan mempengaruhi seseorang untuk meningkatkan prestasi kerja.

Adanya perbedaan situasi sosial dalam hal pendidikan, pengetahuan dan ketrampilan dapat menimbulkan ketidakpuasan, karena itu keadaan ini harus ditekan agar pemberian motivasi sesuai dengan prestasi masingmasing karyawan, juga harus diciptakan suasana yang mendorong kearah kerja sama atas dasar saling membutuhkan, baik antara sesama karyawan maupun dengan atasan dan bawahan, sehingga tercipta situasi dalam organisasi yang menunjang untuk berprestasi.

Begitu juga dalam suatu lembaga pendidikan, suatu lembaga pendidikan akan berjalan efektif apabila sumber daya manusia yang ada dalam lembaga pendidikan teresbut mempunyai motivasi kerja yang tinggi, sehingga dengan motivasi tersebut dapat meningkatkan kerja sama untuk mendorong semua karyawan bekerja dengan giat dan berprestasi.Kesemuanya itu tidak lepas 
dari pengaruh kepemimpinan yang dijalankan dengan baik dan cocok dengan situasi dan kondisi lembaga pendidikan, karyawan yang terdiri dari tenaga pendidik dan kependidkan termotivasi untuk terus berprestasi dalam mencapai tujuan yang di inginkan oleh lembaga pendidikan. Kinerja karyawan merupakan suatu ukuran yang dapat digunakan untuk menetapkan dan membandingan hasil pelaksanaan tugas, tanggung jawab yang diberikan oleh organisasi pada periode tertentu dan relatif dapat digunakan untuk mengukur prestasi kerja atau hasil kinerja organisasi ${ }^{2}$

Melihat pentingnya peranan sumber daya manusia dalam lembaga pendidikan maka tidaklah berlebihan jika dikatakan bahwa, manusia adalah aset yang paling penting yang berdampak pada kesejahteraan lembaga pendidikan secara langsung dibandingkan sumber daya yang lain. Melihat hal tersebut diatas maka salah satu bentuk kepemimpinan dapat kita amati dalam suatu beberapa lembaga pendidikan, salah satunya lembaga pendidikan di Di Madrasah Mu'allimin Mu'allimat Pondok Pesantren Sunan Drajat Lamongan.

Kepemimpinan memegang peranan penting yang akan menggerakkan dan mengarahkan organisasi dalam pencapaian tujuan dan seorang pemimpin lembaga pendidikan haruslah memiliki kemampuan mempengaruhi, motivasi pada karyawannya, yang berdampak pada peningkatan kinerja ${ }^{3}$. Melalui kepemimpinan akan tercipta kinerja karyawan yang sesuai dengan apa yang diharapkan. Kinerja karyawan merupakan tolak ukur akan keberhasilan dari suatu kepemimpinan yang telah dilakukan oleh seorang pemimpin. Kinerja karyawan ${ }^{4}$ adalah prestasi kerja atau hasil kerja baik secara kualitas maupun kuantitas yang dapat dicapai oleh karyawan dalam periode waktu pelaksanaan tugas kerjanya sesuai dengan tanggung jawab yang diberikan kepadanya. Kinerja ${ }^{5}$ merupakan hasil kerja seorang di dalam proses manajemen atau suatu organisasi secara keseluruhan yang

2 Dewi Sandy Trang, "Gaya Kepemimpinan Dan Budaya Organisasi Pengaruhnya Terhadap Kinerja Karyawan (Studi Pada Perwakilan Bpkp Provinsi Sulawesi Utara)," Jurnal Emba 1, no. 3 (2013): 208-16.

3 Desak Ketut Sintaasih I Nyoman Jaka Alit Wiratama, "Pengaruh Kepemimpinan, Diklat, Dan Disiplin Kerja Terhadap Kinerja Karyawan PDAM Tirta Mangutama Kabupaten Badung," Jurnal Manajemen, Strategi Bisnis, Dan Kewirausahaan V7, no. 2 (2013): 126-34.

4 A.A.Anwar Prabu Mangkunegara, Manajemen Sumber Daya Manusia Perusahaan (Bandung: PT. Remaja Rosda Karya, 2006).

${ }^{5}$ Sedarmayanti, Manajemen Sumber Daya Manusia : Reformasi Birokrasi Dan Manajemen Pegawai Negeri Sipil. (Bandung: PT. Refika Aditama, 2007). 
EVALUASI, 3(2), September 2019, ISSN 2580-3387 (print) |

ISSN 2615-2886 (online)

http://doi.org/10.32478/evaluasi.v3i2.265

dapat dibuktikan secara kongkrit dan dapat diukur dalam standar yang telah ditentukan

Seorang pemimpin adalah pencipta semangat dan gairah kerja bagi seluruh pegawainya. Pemimpin juga harus bisa menjelaskan visi dan misi organisasi dengan baik dan mengarahkan pegawai-pegawainya kepada tujuan yang jelas. Kepemimpinan adalah bagian dari kemampuan untuk mempengaruhi orang lain untuk mencapai tujuan dengan antusias. kepemimpinan adalah proses mempengaruhi serta memberi contoh kepada para pegawainya lewat proses komunikasi dalam upaya mencapai tujuan organisasi. Kepemimpinan ${ }^{6}$ adalah proses mempengaruhi dari seorang individu terhadap orang lain untuk mencapai sebuah tujuan bersama.

Kepemimpinan ${ }^{7}$ adalah kemampuan untuk mempengaruhi kelompok menuju pencapaian sasaran. Kepemimpinan ${ }^{8}$ adalah proses untuk mempengaruhi aktifitas kelompok yang diatur untuk mencapai tujuan bersama. Kepemimpinan adalah suatu proses memberi arti pada kerjasama dan dihasilkan dengan kemauan untuk memimpin dalam mencapai tujuan. Kepemimpinan ${ }^{9}$ adalah penggunaan pengaruh dalam perangkat atau situasi organisasi, yang menghasilkan sesuatu yang bermakna dan berdampak langsung pada tujuan-tujuan yang menantang.

Kepemimpinan di lembaga pendidikan sangat tergantung pada karakter dari kepala sekolah dan semua komponen dalam lingkungan sekolah. Interaksi antara tenaga pendidik dengan peserta didik akan menjadikan keberhasilan suatu pendidikan. Kepemimpinan ${ }^{10}$ merupakan suatu pola perilaku para pemimpin dalam mengarahkan dan mengendalikan para bawahan untuk mengikuti kehendaknya dalam mencapai suatu tujuan dan sasaran yang telah ditetapkan. Secara sederhana dapat dikatakan bahwa

${ }^{6}$ Robert and Angelo Kinicki Kreitner, Organizational Behaviour, Eight Edit (New York: McGraw-Hill/Irwin, 2008).

7 S. P. Robbins, Teori Organisasi : Struktur Desain Dan Aplikasi ( Alih Bahasa: Yusuf Udaya ) (Jakarta: Arcan., 2006).

8 Jacob and Jacques, The Relationship Among Principal Leadership, School Culture, and Student Achievment In Missouri Midle Schools (Columbia: University of Missouri, 2008).

9 Ivancevich Robert Konopaske and Michael T. Matteson., Organizational Behaviour and Management, Eight Edition. International Edition. (New York: McGraw-Hill/Irwin, 2008).

10 Kamal Bustomi Ester Manik, "Pengaruh Kepemimpinan Kepala Sekolah, Budaya Organisasi Dan Motivasi Kerja Terhadap Kinerja Guru Pada SMP Negeri 3 Rancaekek," Jurnal Ekonomi, Bisnis \& Entrepreneurship 5, no. 2 (2011): 97-107. 
kepemimpinan merupakan cara yang dipergunakan oleh seorang pemimpin dalam mempengaruhi bawahannya yaitu tenaga pendidik dan tenaga kependidikan. Cara dalam mempengaruhi tenaga pendidik dan tenaga kependidikan akan menciptakan budaya dari lembaga pendidkan yang dipimpinnya.

Guru ${ }^{11}$ sebagai tenaga pendidik merupakan pemimpin pendidikan, dia amat menentukan dalam proses pembelajaran di kelas, dan peran kepemimpinan tersebut akan tercermin dari bagaimana guru melaksanakan peran dan tugasnya, ini berarti bahwa kinerja guru merupakan faktor yang amat menentukan bagi mutu pendidikan yang akan berimplikasi pada kualitas output ( alumni ) pendidikan setelah menyelasaikan sekolah. Guru atau tenaga pendidik ${ }^{12}$ merupakan komponen paling menentukan dalam sistem pendidikan secara keseluruhan, yang harus mendapat perhatian sentral, pertama dan utama. Guru merupakan public figure yang akan senantiasa menjadi sorotan strategis ketika berbicara masalah pendidikan, termasuk dalam sistem pendidikan. Guru memegang peran utama dalam pembangunan pendidikan, khususnya yang diselenggarakan secara formal di sekolah. Guru juga sangat menentukan keberhasilan peserta didik, terutama dalam kaitannya dengan proses belajar mengajar. sedangkan pendidikan pada hakikatnya merupakan sebuah proses bagi seseorang untuk memperoleh ilmu pengetahuan yang nantinya dapat dimanfaatkan untuk masa depan ${ }^{13}$

Rendahnya kinerja guru akan berpengaruh terhadap pelaksanaan tugas yang pada gilirannya akan berpengaruh pula terhadap pencapaian tujuan pendidikan. Dengan demikian keterampilan manajerial yang dimiliki kepala sekolah dalam membangun dan mempertahankan kinerja guru sangat dibutuhkan. Kemampuan manajerial kepala sekolah adalah seperangkat keterampilan teknis dalam melaksanakan tugas sebagai pimpinan sekolah untuk mendayagunakan segala sumber potensi yang tersedia dalam

11 Engkay Karweti, “Pengaruh Kemampuan Manajerial Kepala Sekolah Dan Faktor Yang Mempengaruhi Motivasi Kerja Terhadap Kinerja Guru SLB Di Kabupaten Subang," Jurnal Penelitian Pendidikan 11, no. 2 (2010): 77-89.

12 Ester Manik, "Pengaruh Kepemimpinan Kepala Sekolah, Budaya Organisasi Dan Motivasi Kerja Terhadap Kinerja Guru Pada SMP Negeri 3 Rancaekek."

13 Miftachul Ulum, "Eksistensi Pendidikan Pesantren: Kritik Terhadap Kapitalisasi Pendidikan," TA'LIM : Jurnal Studi Pendidikan Islam 1, no. 2 (2018): 2037. 
mencapai tujuan sekolah atau lembaga pendidikan. Kepala sekolah sebagai seorang tenaga fungsional guru yang berupa beban tugas untuk memimpin suatu sekolah dimana diselenggarakan proses belajar mengajar, atau tempat dimana terjadi interaksi antara guru yang memberi pelajaran dan murid yang menerima pelajaran. Dalam menerapkan kepemimpinannya, seorang kepala sekolah dituntut untuk menerapkan gaya kepemimpinan yang dimilikinya. Gaya kepemimpinan ${ }^{15}$ adalah perilaku dan strategi, sebagai hasil kombinasi dari falsafah, keterampilan, sifat, sikap, yang sering diterapkan seorang pemimpin ketika ia mencoba mempengaruhi kinerja bawahannya. Gaya kepemimpinan ${ }^{16}$ merupakan norma perilaku yang digunakan oleh seseorang pada saat orang tersebut mencoba mempengaruhi perilaku orang lain. Gaya kepemimpinan cocok apabila tujuan perusahaan telah dikomunikasikan dan bawahan telah menerimanya. Seorang pemimpin harus menerapkan gaya kepemimpinan untuk mengelola bawahannya, karena seorang pemimpin akan sangat mempengaruhi keberhasilan organisasi dalam mencapai tujuannya. Tipe-tipe kepemimpinan ${ }^{17}$ terbagi menjadi enam yaitu:

1. Tipe Pribadi, yaitu kepemimpinannya didasarkan pada kontak pribadi secara langsung dengan bawahan-bawahannya.

2. Tipe Nonpribadi, yaitu pimpinan memberikan cermin kurang adanya kontak pribadi pemimpinan yang bersangkutan dengan bawahanbawahanya.

3. Tipe Otoriter, yaitu pemimpin menganggap kepemimpinannya merupakan hak pribadinya dan berpendapat bahwa dia dapat menentukan apa saja dalam organisasi, tanpa mengadakan konsultasi dengan bawahan-bawahannya yang melaksanakan.

4. Tipe Demokratis, yaitu pemimpin menitik beratkan pada partisipasi kelompokdengan memanfaatkan pandangan-pandangan atau pendapat-pendapat kelompok.

14 Wahjosumidjo, Kepemimpinan Kepala Sekolah Tinjauan Teoritik Dan Permasalahannya (Jakarta: Raja Grafindo Persada, 2003).

15 Tampubolon, “Analisa Faktor Gaya Kepemimpinan Dan Faktor Etos Kerja Terhadap Kinerja Pegawai Pada Organisasi Yang Telah Menerapkan SNI 19-90012001."

${ }^{16}$ Juni Dwi Astono, "Pengaruh Tingkat Pendidikan, Pengalaman Kerja, Dan Gaya Kepemimpinan Terhadap Kinerja Melalui Disiplin Kerja Karyawan Dinas Pekerjaan Umum Provinsi Kalimantan Tengah," JSM (Jurnal Sains Manajemen) Program Magister Sains Manajemen UNPAR II, no. September (2013): 36-49.

17 Leslie W. Terry, George R. dan Rue, Dasar -Dasar Manajemen. (Jakarta: Bumi Aksara, 2005). 
EVALUASI, 3(2), September 2019, ISSN 2580-3387 (print) |

ISSN 2615-2886 (online)

http://doi.org/10.32478/evaluasi.v3i2.265

5. Tipe Paternalistis, yaitu pemimpin cenderung terlalu ke-"bapak"an,sehingga sangat memikirkan keinginan dan kesejahteraan anak buah, terlalu melindungi dan membimbing ("overprotective").

6. Tipe Indegenous, yaitu pemimpin yang berinteraksi dimana interaksi antarorang seorang dalam organisasi ditentukan oleh keaslian sifat dan pembawaan pimpinan tersebut.

Sedangkan gaya kepemimpinan ${ }^{18}$ diidentifikasikan menjadi dua gaya kepemimpinan :

1. Gaya dengan orientasi tugas (task-oriented), yaitu: manajer mengarahkan dan mengawasi bawahan secara tertutup untuk menjamin bahwa tugas dilaksanakan sesuai yang diinginkan. Manajer dengan gaya kepemimpinan ini lebih memperhatikan pelaksanaan pekerjaan dari pada perkembangan dan pertumbuhan karyawan.

2. Gaya dengan orientasi karyawan (employee-oriented), yaitu: manajer yang berusaha untuk mencoba lebih memotivasi bawahan dibanding mengawasi mereka. Mendorong para anggota kelompok untuk melaksanakan tugas-tugas dengan membeikan kesempatan bawahan untuk berpartisipasi dalam pembuatan keputusan, menciptakan suasana persahabatan serta hubungan-hubungan saling mempercayai dan menghormati dengan para anggota kelompok.

Hasil penelitiannya ${ }^{19}$ kepemimpinan mempunyai peranan dalam yang terpenting dalam menciptakan realitas organisasi dan membentuk budaya organisasi. Produktivitas adalah kinerja guru akan bisa terwujud jika ditopang oleh budaya organisasi yang kuat dan iklim organisasi yang kondusif. Hal tersebut menunjukkan bahwa gaya kepemimpinan yang diterapkan oleh kepala sekolah akan mempengaruhi terbentuknya budaya dan iklim organisasi yang ada di sekolah. Senada dengan apa yang dikatakan Kartono bahwa fungsi kepemimpinan adalah memandu, menuntun, membimbing, membangun memberi atau membangunkan motivasi-motivasi kerja, mengemudikan organisasi, menjalin jaringan komunikasi yang baik, memberikan supervisi, pengawasan yang efisien dan membawa pengikutnya kepada sasaran yang ingin dituju sesuai dengan ketentuan dan perencanaan. Hal ini menunjukan bahwa ada hubungan positif kepemimpinan kepala

18 T. Hani Handoko, Dasar-Dasar Manajemen Dan Operasi, I (Yogyakarta: BPFE, 1999), 299.

19 Hikmah Eva Trisnantari, "Hubungan Antara Gaya Kepemimpinan Kepala Sekolah Dengan Budaya Organisasi Di SMP Negeri Kabupaten Tulungagung.," DINAMIKA 9, no. 1 (2009). 
sekolah dengan motivasi kerja guru ${ }^{20}$. Terkait dengan pendapat Kartono tersebut bahwa gaya kepemimpinan dapatlah dikembangkan sebagaimana pendapat dari Kreitner tentang Teori kepemimpinan ${ }^{21}$ bahwa gaya kepemimpinan seorang manajer dapat dikembangkan dan diperbaiki secara sistematik. Seorang pemimpin dalam menghadapi situasi yang menuntut gaya kepemimpinannya dapat melalui beberapa proses seperti: memahami gaya kepemimpinannya, mendiagnosa suatu situasi, menerapkan gaya kepemimpinan yang relevan dengan tuntutan situasi atau dengan mengubah situasi agar sesuai dengan gaya kepemimpinannya. Hal ini akan mendorong timbulnya itikad baik atau komitmen anggota terhadap organisasinya.

Ahmad Fadli dalam penelitian dengan judul "Pengaruh Gaya Kepemimpinan Terhadap Kinerja Karyawan Pada PT. Kawasan Industri Medan" dan penelitian dari Ari Heryanto dengan judul "Pengaruh Gaya Kepemimpinan Terhadap Kinerja Karyawan membuktikan bahwa ecara empiris gaya kepemimpinan mempunyai pengaruh yang positif dan signifikan terhadap kinerja karyawan. Pengaruh ini menunjukkan adanya pengaruh yang searah antara gaya kepemimpinan dengan kinerja karyawan, yang berarti bahwa dengan gaya kepemimpinan baik maka kinerja karyawan tinggi. Sedangkan pengaruh yang signifikan ini menunjukkan bahwa gaya kepemimpinan berpengaruh secara nyata terhadap kinerja karyawan ${ }^{22}$. Prestasi kerja adalah hasil kerja seorang karyawan selama periode tertentu dibandingkan dengan berbagai kemungkinan, misalnya stardar, target / sasaran atau kriteria yang telah ditentukan terlebih dahulu dan telah disepakati bersama ${ }^{23}$. Pengertian kinerja (prestasi kerja) adalah kualitas yang dicapai oleh seorang pegawai dalam melaksanakan tugasnya sesuai dengan tanggung jawab yang diberikan kepadanya. Prestasi kerja perlu dilakukan suatu penilaian untuk mengetahui prestasi yang dicapai oleh seorang karyawan ${ }^{24}$. Penilaian prestasi kerja merupakan bagian dari usaha

${ }^{20}$ Ester Manik, “Pengaruh Kepemimpinan Kepala Sekolah, Budaya Organisasi Dan Motivasi Kerja Terhadap Kinerja Guru Pada SMP Negeri 3 Rancaekek."

${ }^{21}$ Kreitner dan Kinichi, Organization Behavior (Boston: McGraw-Hill, 1998).

22 Muhammad Fauzan Baihaqi, "Pengaruh Gaya Kepemimpinan Terhadap Kepuasan Kerja Dan Kinerja Dengan Komitmen Organisasi Sebagai Variabel Intervening ( Studi Pada PT. Yudhistira Ghalia Indonesia Area Yogyakarta )" (Universitas Diponegoro Semarang, 2010).

${ }^{23}$ John Soeprihanto, Pengantar Bisnis, 2nd ed. (Yogyakarta: STIE YKPN., 2007), 7.

24 Anwar Prabu Mangkunegara, Manajemen Sumber Daya Manusia Perusahaan, 2nd ed. (Bandung: PT. Remaja Rosdakarya Offset, 2000), 67. 
memperbaiki keputusan-keputusan dan sebagai cermin diri atau umpan balik bagi karyawan tentang pelaksanaan kerja mereka. Menurut Soeprihanto tujuan penilaian prestasi kerja adalah sebagai berikut:

a. Mengetahui keterampilan dan kemampuan setiap karyawan dari waktu kewaktu.

b. Penilaian digunakan sebagai dasar perencanaan bidang personalia, khususnya penyempurnaan kondisi kerja, peningkatan mutu dan hasil kerja.

c. Prestasi kerja dijadikan sebagai dasar pengembangan dan pendayagunaan karyawan seoptimal mungkin, misalnya jenjang karier, kenaikan pangkat dan jabatan.

d. Mendorong terciptanya hubungan timbale balik antara atasan dan bawahan.

e. Penilaian bagi karyawan dapat mengetahui kekuatan dan kelemahan masing-masing yang dapat memacu dan bagi atasan yang menilai alebih memperhatikan karyawannya, ssehingga dapat membantu memotivasi karyawan dalam bekerja.

f. Hasil penilaian pelaksanaan pekerjaan dapat bermanfaat bagi penilaian dan perkembangan dibidang personalia secara keseluruhan.

Sedangkan menurut Handoko penilaian prestasi kerja yang dilakukan memiliki beberapa kegunaan diantaranya yaitu:

1. Perbaikan prestasi kerja. Umpan balik pelaksanaan kerja memungkinkan karyawan, manager dan departemen personalia dapat memperbaiki prestasinya.

2. Penyesuain-penyesuaian kompensasi. Evaluasi prestasi kerja membantu para pengambil keputusan dalam menentukan kenaikan upah, pemberian bonus dan bentuk kompensasi lainnya.

3. Keputusan-keputusan penempatan. Promosi, transfer dan demosi biasanya didasarkan pada prestasi kerja masa lalu atau antisipasinya. Promosi biasanya merupakan bentuk penghargaan terhadap prestasi kerja masa lalu.

4. Kebutuhan-kebutuhan latihan dan pengembangan. Prestasi kerja yang jelek mungkin menunjukkan kebutuhan latihan. Demikian juga, prestasi yang baik mungkin mencerminkan potensi yang harus dikembangkan.

5. Perencanaan dan pengembangan karier. Umpan balik prestasi mengarahkan keputusan-keputusan karier, yaitu tentang jalur karier yang harus diteliti. 
EVALUASI, 3(2), September 2019, ISSN 2580-3387 (print) |

ISSN 2615-2886 (online)

http://doi.org/10.32478/evaluasi.v3i2.265

6. Penyimpangan-penyimpangan proses staffing. Prestasi kerja yang baik atau jelek menceminkan kekuatan atau kelemahan prosedur staffing departemen personalia.

7. Ketidak-akuratan informasi. Prestasi kerja yang jelek mungkin menunjukkan kesalahan-kesalahan dalam informasi analisis jabatan, rencana-rencana sumberdaya manusia, atau komponen-komponen lain system informasi manajemen personalia.

8. Kesalahan-kesalahan desain pekerjaan. Prestasi yang jelek mungkin merupakan suatu tanda kesalahan dalam desain pekerjaan. Penilaian prestasi kerja membantu diagnosa kesalahan-kesalahan tersebut.

9. Kesempatan kerja yang adil. Prestasi Penilaian kerja secara akuratakan menjamin keputusan-keputusan penempatan internal diambil tanpa diskriminasi.

10. Tantangan-tantangan eksternal. Kadang-kadang prestasi kerja dipengaruhi oleh faktor-faktor diluarlingkungan kerja, seperti keluarga, kesehatan, kondisi finansial atau masalah-masalah pribadi lainnya. Dengan penilain prestasi mungkin departemen personalia dapat menawarkan bantuan.

Jadi dengan penilaian prestasi kerja dapat diketahui prestasi kerja seorang karyawan yang memiliki kelebihan dan kekurangan yang berbedabeda. Karyawan yang memiliki prestasi tinggi memungkinkan dirinya untk diberikan promosi, sebaliknya karyawan yang berprestasi rendah dapat diperbaiki prestasi kerjanya melalui pendidikan dan latihan dalam rangka pengembangan karyawan.

\section{B. METODE PENELITIAN}

\section{Jenis Penelitian}

Pendekatan penelitian ini merupakan penelitian jenis penelitian survey. yang dilakukan pada populasi besar maupun kecil, tetapi data yang dipelajari adalah data dari sampel yang diambil dari populasi tersebut, sehingga ditemukan kejadian-kejadian relative, distribusi, dan hubunganhubungan antar variabel.

Populasi dalam penelitian ini adalah semua karyawan dan guru yang bekerja di Madrasah Mu'allimin Mu'alimat Sunan Drajat Banjarwati yaitu berjumlah 45 orang. Dalam penelitian ini penulis menggunakan studi populasi, karena yang dijadikan sasaran penelitian adalah seluruh individu yang ada. Sampel ini diambil dari seluruh karyawan yang ada di Madrasah Mu'allimin Mu'alimat Sunan Drajat Banjarwati yang berjumlah 45 orang. 
EVALUASI, 3(2), September 2019, ISSN 2580-3387 (print) |

ISSN 2615-2886 (online)

http://doi.org/10.32478/evaluasi.v3i2.265

Sedangkan hipotesa yang diajukan bahwa kepemimpinan mempunyai pengaruh terhadap prestasi kerja karyawan Di Madrasah Mu'allimin Mu'allimat Pondok Pesantren Sunan Drajat Lamongan

\section{Metode Pengumpulan Data}

a. Teknik kuisioner

Teknik ini digunakan untuk memperoleh data primer mengenai persepsi karyawan Madrsah Mu'allimin Mu'alimat Sunan Drajat Banjarwati tentang kepemimpinan yang ada di Madrasah Mu'allimin Mu'alimat Sunan Drajat, dengan memberikan kuesioner tertutup yaitu daftar pertanyaan yang telah disediakan alternatif jawaban, sehingga responden dapat memilih salah satu jawaban yang dianggap sesuai dengan menggunakan skala likert.

b.Teknik Dokumentasi

Teknik dokumentasi digunakan untuk memperoleh data sekunder berupa dokumen dari pihak manajemen di Madrasah Mu'allimin Mu'alimat Sunan Drajat Banjarwati yang akan digunakan untuk melengkapi data dari hasil angket.

\section{Variabel Penelitian}

Dalam penelitian ini variabel yang digunakan adalah:

a. Kepemimpinan (variabel bebas/ $x$ )

Kepemimpinan adalah kemampun untuk mengendalikan, mempengaruhi dan mengarahkan orang lain untuk tercapainya suatu tujuan tetentu. Dalam kenyataannya kepemimpinan dapat mempengaruhi prestasi kerja karyawan.

b. Prestasi kerja (variabel terikat / y)

Prestasi kerja adalah hasil kerja seseorang didalam melaksanakan suatu pekerjaan dengan standar, target/sasaran atau kriteria yang telah ditentukan dan disepakati bersama.

\section{Metode Analisis data}

Metoda analisis data yang digunakan adalah teknik analisis regresi untuk mengetahui apakah suatu gejala atau variabel dapat digunakan untuk memprediksi gejala atau variabel yang lain yang kemudian dilakukan pengujian pengujian statiatik, dalam penelitian ini bermaksud untuk mengetahui pengaruh variabel $X$ terhadap variabel $Y$ dengan menggunakan beberapa pengujian diantaranya yaitu: 
EVALUASI, 3(2), September 2019, ISSN 2580-3387 (print) |

ISSN 2615-2886 (online)

http://doi.org/10.32478/evaluasi.v3i2.265

a. Uji Validitas

Sebelum pengujian statistik, perlu dilakukan pengujian validitas dan reliabilitas yang merupakan dua persaratan penting sebuah angket. Analisis dimulai dengan menguji validitas terlebih dahulu, setelah itu reliabilitas. Jadi jika sebuah butir tidak valid, maka otomatis dibuang atau dihilangkan. Butir yang sudah valid kemudian diukur reliabilitasnya

Penelitian perlu dilakukan pengujian mengenai sejauh mana alat ukur yang digunakan untuk mendapatkan data valid dan reliabel. Valid berarti alat ukur yang digunakan benar-benar mengukur apa yang hendak diukur, karena alat yang digunakan adalah kuesioner maka validitas alat ukurnya mengandung arti apakah pertanyan-pertanyaan dalam kuesioner cukup sahih untuk mengukur variabel penelitian.

b. Uji Reliabilitas

Uji reliabilitas dilakukan untuk menguji sejauh mana hasil pengukuran dapat diandalkan atau dapat dipercaya. Reliabilitas mempunyai arti tingkat kepercayaan dari hasil suatu pengukuran. Alat ukur yang reliabel berarti alat ukur yang apabila digunakan beberapa kali untuk mengukur objek yang sama akan memberikan hasil yang relatif sama.

c.Analisis regresi linear

Regresi linear sederhana adalah teknik regresi yang hanya terdapat satu variabel bebas $(\mathrm{m})$, untuk mengadakan prediksi terhadap variabel terikat. Persamaan regresi linear adalah:

$$
\mathrm{Y}=\mathrm{a}+\mathrm{bX}
$$

Keterangan:

$\mathrm{Y}=$ variabel terikat (prestasi kerja)

$\mathrm{a}=$ konstanta (harga $\mathrm{Y}$ bila $\mathrm{X}=0$ )

$X=$ variabel bebas (kepemimpinan)

$\mathrm{b}=$ koefesien regresi

\section{HASIL DAN PEMBAHASAN}

\section{Profil Responden dan Diskripsi Statistik}

Karakteristik responden karyawan di Madrasah Mu'allimin Mu'alimat Sunan Drajat Banjarwati yang dijadikan sampel terangkum sebagai berikut : 
EVALUASI, 3(2), September 2019, ISSN 2580-3387 (print) |

ISSN 2615-2886 (online)

http://doi.org/10.32478/evaluasi.v3i2.265

Tabel 1

Tingkat Pendidikan Responden

\begin{tabular}{|c|c|c|}
\hline Pendidikan & Responden & Persentase (\%) \\
\hline Pesantren & 5 & $11,11 \%$ \\
SLTA & 2 & $4,44 \%$ \\
D2/3 & 2 & $4,44 \%$ \\
S1 & 29 & $64,44 \%$ \\
S2 & 7 & $15,55 \%$ \\
\hline Jumlah & 45 & $100 \%$ \\
\hline \multicolumn{3}{|c}{ (Sumber: data kuisioner) }
\end{tabular}

Berdasarkan hasil penelitian yang dilakukan terhadap para responden yang merupakan tenaga pendidik dan kependidikan maka diperoleh jumlah responden berpendidikan S1 (64,44\%), berpendidikan S2 adalah 15,55\%, pendidikan D2/3 sebesar 4,44 \%, dan yang berpendidikan SLTP juga sebesar 4,44 \%, dan terdapat 7 (tujuh) karyawan yang hanya lulusan pesantren/tidak berijazah sebesar $11,11 \%$. Hal ini berarti sebagian besar karyawan Madrasah Mu'allimin Mu'alimat Sunan Drajat Banjarwati berpendidikan S1.

Tabel 2

Jenis Kelamin Responden

\begin{tabular}{|c|c|c|}
\hline jenis kelamin & Responden & Persentase \\
\hline Pria & 40 & $88,89 \%$ \\
Wanita & 5 & $11,11 \%$ \\
\hline Jumlah & 45 & $100 \%$ \\
\hline
\end{tabular}

(Sumber: data kuisioner)

Berdasarkan data jenis kelamin maka karyawan Madrasah Mu'allimin Mu'alimat Sunan Drajat di dominasi oleh pria sebesar 88,89 \%, sedangkan $11,11 \%$ berjenis kelamin wanita. 
EVALUASI, 3(2), September 2019, ISSN 2580-3387 (print) |

ISSN 2615-2886 (online)

http://doi.org/10.32478/evaluasi.v3i2.265

Tabel 3

Status Perkawinan Responden

\begin{tabular}{|c|c|c|}
\hline Status Perkawinan & Responden & Persentase (\%) \\
\hline Belum Menikah & 9 & $20 \%$ \\
Menikah & 35 & $77,78 \%$ \\
Duda/Janda & 1 & $2,22 \%$ \\
\hline Jumlah & 45 & $100 \%$ \\
\hline
\end{tabular}

(Sumber: data kuisioner)

Berdasarkan status perkawinan terdapat 9 responden yang belum menikah dengan persentase sebesar $20 \%$, sedangkan 2,22 \% berstatus janda dan status menikah sebesar $77,78 \%$ responden yang berjumlah 35 . Jadi mayoritas responden adalah sudah menikah.

Tabel 4

Masa Kerja Responden

\begin{tabular}{|c|c|c|}
\hline Masa Kerja & Responden & Persentase (\%) \\
\hline > 14 Th & 10 & $22,22 \%$ \\
10 Th Sampai Dengan 14 Th & 6 & $13,33 \%$ \\
5 Th Sampai Dengan < 10 Th & 14 & $31,11 \%$ \\
<5 Th & 15 & $33,33 \%$ \\
\hline Jumlah & 45 & $100 \%$ \\
\hline
\end{tabular}

(Sumber: data kuisioner)

Masa kerja responden mempunyai masa kerja $<5$ tahun sebanyak 33,33\% dan pada masa $5-<10$ tahun sebesar $31,11 \%$, sedangkan yang mempunyai masa kerja lebih dari 14 tahun sebesar 22,22 \% dan enam karyawan dengan masa kerja 10 tahun -14 tahun dengan persentase $13,33 \%$.

Dari hasil pengolahan data dengan program SPSS ${ }^{25}$ diperoleh gambaran variabel data penelitian yang terangkum dalam diskripsi data statistic sebagai berikut :

25 Miftachul Ulum, Mahir Analisa Data SPSS Statistical Product, Service Solution (Yogyakarta: Ghaneswara, 2013). 
EVALUASI, 3(2), September 2019, ISSN 2580-3387 (print) |

ISSN 2615-2886 (online)

http://doi.org/10.32478/evaluasi.v3i2.265

Tabel. 5

Deskripsi Statistik

\begin{tabular}{|l|r|r|r|r|r|}
\hline & $\mathrm{N}$ & Minimum & Maximum & Mea & Std. \\
\hline Prestasi & 45 & 20 & 35 & 26,53 & 3,341 \\
Kepemimpin & 45 & 16 & 35 & 28,87 & 3,375 \\
Valid N & 45 & & & & \\
\hline
\end{tabular}

(Sumber: hasil pengolahan dengan SPSS)

Berdasarkan deskripsi statistik diatas, peneliti menggolongkan subjek (responden) ke dalam tiga kategori diagnosis tingkat kepemimpinan terhadap prestasi kerja karyawan, yaitu tinggi, sedang, dan rendah. Hasil pengkategorian tingkat kepemimpinan dan prestasi kerja dapat dilihat pada dua tabel berikut :

Tabel. 6

Distribusi skor Kepemimpinan

\begin{tabular}{|c|c|c|c|}
\hline skor & Kategori & Frekwensi & $\%$ \\
\hline $32-35$ & Tinggi & 9 & 19,9 \\
\hline $28-31$ & Sedang & 24 & 53,4 \\
\hline $16-27$ & Rendah & 12 & 26,7 \\
\hline
\end{tabular}

(Sumber: data kuisioner)

Tabel diatas menunjukkan bahwa sebagian besar karyawan dalam tingkat kepuasaan kepemimpinan yang sedang $(53,4 \%)$ sebagian memiliki tingkat kepuasan kepemimpinan yang rendah $(26,7 \%)$ dan tinggi $(19,9 \%)$ dari seluruh jumlah responden.

Tabel. 7

Distribusi skor Prestasi Kerja

\begin{tabular}{|c|c|c|c|}
\hline skor & Kategori & Frekwensi & $\%$ \\
\hline $29-35$ & Tinggi & 13 & 28,8 \\
\hline $25-28$ & Sedang & 19 & 42,3 \\
\hline $20-24$ & Rendah & 13 & 28,9 \\
\hline
\end{tabular}

(Sumber: data kuisioner) 
Tabel diatas menunjukkan bahwa sebagian besar karyawan memiliki tingkat prestasi kerja yang sedang $(42,3 \%)$ sebagian memiliki tingkat prestasi kerja yang tinggi $(28,8 \%)$ dan rendah $(28,9 \%)$ dari seluruh jumlah responden.

Berdasarkan hasil pengkategorian tingkat kepemimpinan dan prestasi kerja yang ditunjukkan pada diatas mengindikasikan bahwa lebih dari setengah karyawan (responden) memiliki tingkat kepemimpinan dan prestasi kerja yang sedang, sebagian tinggi dan sebagian kecil berada pada tingkat rendah.

\section{Analisa Data}

a. Uji Validitas

Uji validitas alat ukur (skala) diketahui dengan menggunakan analisis kesahihan butir. Uji validitas skala kepemimpinan menunjukkan bahwa dari 7 item pertanyaan tidak terdapat satu itempun yang gugur, rentang koefisien validitas ( $\mathrm{rxy}$ ) yang shahih bergerak antara $0,547 \mathrm{~s} / \mathrm{d} 0,752$ dan peluang galat (p) sebesar 0,000

Uji validitas skala prestasi kerja menunjukkan bahwa dari 7 item pertanyaan tidak terdapat satu itempun yang gugur, rentang koefisien validitas ( $r x y$ ) yang sahih bergerak antara $0,498 \mathrm{~s} / \mathrm{d} 0,640$ dan peluang galat (p) sebesar 0,000 Berdasarkan hasil analisis kesahihan butir (validitas) diatas, maka item pertanyaan tersebut dapat digunakan sebagai alat/instrumen pengumpul data peneliti. Hal itu disebabkan karena kedua skala (item pertanyaan masing-masing variabel) diatas sudah mencapai keshahihan yang baik, dimana peluang galat atau peluang kesalahan berada dibawah 0,05 atau kurang dari $5 \%$.

\section{b. Uji Reliabilitas}

Hasil analisis uji reliabilitas menunjukkan bahwa koefisien reliabilitas yang dilihat dari besarnya Alpha item pertanyaan variabel kepemimpinan sebesar 0,7583 koefisien reliabilitas item pertanyaan variabel prestasi kerja sebesar 0,7262. Berdasarkan hasil analisis yang diperoleh diatas, maka item pertanyaan tersebut dapat digunakan sebagai alat/instrumen pengumpul data peneliti. Hal itu disebabkan karena kedua skala (item pertanyaan masing-masing variabel) diatas sudah mencapai keandalan yang baik, dimana tingkat koefisien reliabilitas (Alpha) diatas atau lebih besar dari 0,60. 
EVALUASI, 3(2), September 2019, ISSN 2580-3387 (print) |

ISSN 2615-2886 (online)

http://doi.org/10.32478/evaluasi.v3i2.265

\section{c. Regresi Linier}

Berdasarkan hasil yang diperoleh dari perhitungan regresi linier dengan menggunakan program statistik SPSS dapat disajikan hasilnya sebagai berikut :

Tabel. 8

Koefisien Regresi

\begin{tabular}{|l|l|l|l|l|}
\hline \multicolumn{1}{|c|}{ Model } & Koefisien & Thitung & Sig & $\begin{array}{l}\text { Standar } \\
\text { Error }\end{array}$ \\
\hline $\begin{array}{l}\text { Konstan } \\
\text { Kepemimpinan }\end{array}$ & 13,736 & 3,502 & 0,001 & 1,874 \\
\hline R $=0,448$ & R square $=0,201$ & F hitung $=10,787$ & Sign. F 0,002 \\
\hline
\end{tabular}

(Sumber: hasil pengolahan dengan SPSS)

Dari tabel diatas dapat dikemukakan hasil persamaan regresi sebagai berikut :

$$
Y=13,736+0,443 X
$$

Dimana :

Y : Prestasi

$\mathrm{X}$ : Kepemimpinan

Konstanta sebesar 13,736 menunjukkan interpretasi dari nilai $Y$ (prestasi) pada saat nilai $X$ sama dengan nol. Koefisien korelasi $X$ sebesar 0 , 443 menunjukkan bahwa arah hubungan variabel $X 1$ dengan $Y$ adalah positif, artinya semakin tinggi nilai kepemimpinan $(X)$ maka nilai prestasi $(Y)$ juga ikut tinggi.

Tabel. 9

Model Summary

\begin{tabular}{|l|r|r|r|r|}
\hline Model & $\mathrm{R}$ & $\mathrm{R}$ Square & $\begin{array}{c}\text { Adjusted } \\
\text { R Square }\end{array}$ & $\begin{array}{c}\text { Std. Error of } \\
\text { the Estimate }\end{array}$ \\
\hline 1 &, $448^{\mathrm{a}}$ &, 201 &, 182 & 3,022 \\
\hline
\end{tabular}

a. Predictors: (Constant), Kepemimpinan

b. Dependent Variable: Prestasi

(Sumber: hasil pengolahan dengan SPSS)

Nilai R (koefisien Regresi) sebesar 0,448 merupakan nilai hubungan secara simultan dari variabel independen terhadap variabel dependen. 
EVALUASI, 3(2), September 2019, ISSN 2580-3387 (print) |

ISSN 2615-2886 (online)

http://doi.org/10.32478/evaluasi.v3i2.265

Sedangkan nilai koefesien determinasi ( $R$ squared ) sebesar 0,201 menunjukkan bahwa variasi variabel terikat prestasi kerja $(\mathrm{Y})$ dijelaskan/dipengaruhi oleh variabel bebas kepemimpinan $(X)$ hanya sebesar 20,1 persen dan sisanya 79,9 persen dipengaruhi oleh variabel atau faktor lain.

\section{d. Pengujian Hipotesis}

Hasil analisis menunjukkan adanya koefisien korelasi sebesar 0,448 dengan peluang galat $(p)$ sebesar 0,002 . hal ini menunjukkan ada pengaruh secara positif dan signifikan dari kepemimpinan terhadap prestasi. Sumbangan efektif dari variabel kepemimpinan kepada variabel prestasi dapat dilihat dari koefisien determinasi ( $R$ Square) sebesar 0,201. Berdasarkan hasil analisis regresi linier diatas dapat disimpulkan bahwa terdapat hubungan yang positif serta signifikan antara kepemimpinan terhadap prestasi kerja pada karyawan Madrasah Mu'allimin Mu'alimat Sunan Drajat Banjarwati. Dengan demikian hipotesis dinyatakan "diterima".

\section{e. Interprestasi Hasil Penelitian}

Berdasarkan hasil deskripsi dan analisis data diatas menunjukkan bahwa dari 45 karyawan (responden) menghasilkan : pertama, tingkat kepemimpinan berada pada kategori sedang $(53,4 \%)$ sebagian lagi berada pada kategori tinggi $(19,9 \%)$ dan sebagian kecil pada kategori rendah $(26,7$ $\%)$. Kedua, tingkat prestasi kerja berada pada kategori sedang (42,3\%) sebagian lagi berada pada kategori tinggi $(28,8 \%)$ dan sebagian kecil pada kategori rendah (28,9\%).

Hal tersebut dapat disimpulkan bahwa sebagian besar karyawan (responden) memiliki tingkat kepuasan kepemimpinan yang sedang dan diikuti dengan prestasi kerja yang sedang juga. karyawan yang memiliki tingkat kepuasaan kepemimpinan yang rendah, sebanyak 12 orang, sementara yang memiliki prestasi kerja yang rendah sebanyak 13 orang. Ada 13 karyawan yang memiliki tingkat prestasi yang tinggi sedangkan yang memiliki tingkat kepuasan kepemimpinan yang tinggi tinggi hanya 9 orang. Kesimpulan di atas adalah sangat wajar mengingat untuk mendapat tingkat kepuasan kepemimpinan yang maksimal sangatlah sulit didapatkan, sehingga akan mempengaruhi prestasi kerja mereka. Mengingat sulitnya mencapai tingkat kepuasaan kepemimpinan yang ideal, maka hasil penelitian terhadap karyawan Madrasah Mu'allimin Mu'alimat Sunan Drajat sudah mengindikasikan bahwa pencitraan terhadap kepemimpinan dapat dikatakan cukup baik. 
Hasil analisis produk moment menunjukkan adanya pengaruh yang dari kepemimpinan terhadap prestasi kerja karyawan Madrasah Mu'allimin Mu'alimat Sunan Drajat. meskipun hal tersebut hanya ditunjukkan dengan adanya pengaruh/korelasi ( $R$ ) sebesar 0.448 dengan peluang galat $(p)$ sebesar 0,000 . sedangkan sumbangan efektif kepemimpinan terhadap prestasi kerja dapat dilihat dari koefisien Determinasi $\left(R^{2}\right)$ sebesar 0.201 yang berarti sumbangan variabel kepemimpinan terhadap prestasi kerja hanya sebesar 20,1 \% selebihnya 79,9\% mengindikasikan adanya kemungkinan faktor lain yang mempengaruhi prestasi kerja pada karyawan Madrasah Mu'allimin Mu'alimat Sunan Drajat.

Kemungkinan besar faktor yang mempengaruhi prestasi kerja adalah faktor motivasi yang berupa lingkungan kerja, kompensasi, dan fasilitas kerja. Lingkungan kerja yang tepat, damai,sejuk dan tentram akan sangat memberikan kontribusi terhadap prestasi kerja karyawan, demikian halnya dengan kompensasi, yang merupakan imbalan yang harus dibayar oleh organisasi kepada setiap karyawan/anggotanya atas jasa yang telah di lakukan. Berdasarkan hasil analisis regresi diatas mengindikasikan bahwa kepemimpinan sangat besar pengaruhnya terhadap prestasi kerja. Sehingga semakin tinggi faktor kepemimpinan yang dirasakan oleh karyawan maka semakin tinggi pula prestasi kerja para karyawan. Sebaliknya semakin rendah kepemimpinan yang dirasakan maka semakin rendah pula tingkat prestasi kerja karyawan.

\section{KESIMPULAN}

Keberhasilan dalam pengelolaan lembaga pendidikan sangat tergantung sekali pada peran guru dan para pengelola yang ada didalamnya. Kepala sekolah sebagi top leader sangat menentukan kinerja dari tenaga pendidik dan tenaga kependidikan. Dari hasil analisis kepemimpinan terhadap prestasi kerja karyawan di Madrasah Mu'allimin Mu'alimat Sunan Drajat menunjukkan adanya suatu hubungan atau korelasi (R) antara kepemimpinan terhadap prestasi kerja karyawan sebesar 0.448 dengan peluang galat (p) sebesar 0,000 . sedangkan sumbangan efektif kepemimpinan terhadap prestasi kerja dapat dilihat dari koefisien Determinasi $\left(R^{2}\right)$ sebesar 0.201 yang berarti sumbangan variabel kepemimpinan terhadap prestasi kerja hanya sebesar 20,1\% selebihnya 79,9 $\%$ mengindikasikan adanya kemungkinan faktor lain yang mempengaruhi prestasi kerja pada karyawan Madrasah Mu'allimin Mu'alimat Sunan Drajat. Dari hasil tersebut menunjukan bahwa hipotesa yang diajukan bahwa 
EVALUASI, 3(2), September 2019, ISSN 2580-3387 (print) |

ISSN 2615-2886 (online)

http://doi.org/10.32478/evaluasi.v3i2.265

kepemimpinan mempunyai pengaruh terhadap prestasi kerja karyawan Di Madrasah Mu'allimin Mu'allimat Pondok Pesantren Sunan Drajat Lamongan diterima

\section{REFERENSI}

Dewi Sandy Trang. "Gaya Kepemimpinan Dan Budaya Organisasi Pengaruhnya Terhadap Kinerja Karyawan (Studi Pada Perwakilan Bpkp Provinsi Sulawesi Utara)." Jurnal Emba 1, no. 3 (2013): 208-16.

Engkay Karweti. "Pengaruh Kemampuan Manajerial Kepala Sekolah Dan Faktor Yang Mempengaruhi Motivasi Kerja Terhadap Kinerja Guru SLB Di Kabupaten Subang." Jurnal Penelitian Pendidikan 11, no. 2 (2010): 77-89.

Ester Manik, Kamal Bustomi. "Pengaruh Kepemimpinan Kepala Sekolah, Budaya Organisasi Dan Motivasi Kerja Terhadap Kinerja Guru Pada SMP Negeri 3 Rancaekek." Jurnal Ekonomi, Bisnis \& Entrepreneurship 5, no. 2 (2011): 97-107.

Hikmah Eva Trisnantari. "Hubungan Antara Gaya Kepemimpinan Kepala Sekolah Dengan Budaya Organisasi Di SMP Negeri Kabupaten Tulungagung." DINAMIKA 9, no. 1 (2009).

I Nyoman Jaka Alit Wiratama, Desak Ketut Sintaasih. "Pengaruh Kepemimpinan, Diklat, Dan Disiplin Kerja Terhadap Kinerja Karyawan PDAM Tirta Mangutama Kabupaten Badung." Jurnal Manajemen, Strategi Bisnis, Dan Kewirausahaan V 7, no. 2 (2013): 126-34.

Ivancevich Robert Konopaske and Michael T. Matteson. Organizational Behaviour and Management, Eight Edition. International Edition. New York: McGraw-Hill//rwin, 2008.

Jacob and Jacques. The Relationship Among Principal Leadership, School Culture, and Student Achievment In Missouri Midle Schools. Columbia: University of Missouri, 2008.

John Soeprihanto. Pengantar Bisnis. 2nd ed. Yogyakarta: STIE YKPN., 2007. 
EVALUASI, 3(2), September 2019, ISSN 2580-3387 (print)|

ISSN 2615-2886 (online)

http://doi.org/10.32478/evaluasi.v3i2.265

Juni Dwi Astono. "Pengaruh Tingkat Pendidikan, Pengalaman Kerja, Dan Gaya Kepemimpinan Terhadap Kinerja Melalui Disiplin Kerja Karyawan Dinas Pekerjaan Umum Provinsi Kalimantan Tengah." JSM (Jurnal Sains Manajemen) Program Magister Sains Manajemen UNPAR II, no. September (2013): 36-49.

Kreitner dan Kinichi. Organization Behavior. Boston: McGraw-Hill, 1998.

Kreitner, Robert and Angelo Kinicki. Organizational Behaviour. Eight Edit. New York: McGraw-Hill/Irwin, 2008.

Mangkunegara, A.A.Anwar Prabu. Manajemen Sumber Daya Manusia Perusahaan. Bandung: PT. Remaja Rosda Karya, 2006.

Mangkunegara, Anwar Prabu. Manajemen Sumber Daya Manusia Perusahaan. 2nd ed. Bandung: PT. Remaja Rosdakarya Offset, 2000.

Miftachul Ulum. "Eksistensi Pendidikan Pesantren: Kritik Terhadap Kapitalisasi Pendidikan." TA'LIM : Jurnal Studi Pendidikan Islam 1, no. 2 (2018): 20-37.

- - Mahir Analisa Data SPSS Statistical Product, Service Solution. Yogyakarta: Ghaneswara, 2013.

Muhammad Fauzan Baihaqi. "Pengaruh Gaya Kepemimpinan Terhadap Kepuasan Kerja Dan Kinerja Dengan Komitmen Organisasi Sebagai Variabel Intervening ( Studi Pada PT. Yudhistira Ghalia Indonesia Area Yogyakarta )." Universitas Diponegoro Semarang, 2010.

Robbins, S. P. Teori Organisasi : Struktur Desain Dan Aplikasi ( Alih Bahasa: Yusuf Udaya ). Jakarta: Arcan., 2006.

Sedarmayanti. Manajemen Sumber Daya Manusia : Reformasi Birokrasi Dan Manajemen Pegawai Negeri Sipil. Bandung: PT. Refika Aditama, 2007.

T. Hani Handoko. Dasar-Dasar Manajemen Dan Operasi. I. Yogyakarta: BPFE, 1999.

Tampubolon, Biatna Dulbert. “Analisa Faktor Gaya Kepemimpinan Dan Faktor Etos Kerja Terhadap Kinerja Pegawai Pada Organisasi Yang Telah 
EVALUASI, 3(2), September 2019, ISSN 2580-3387 (print) |

ISSN 2615-2886 (online)

http://doi.org/10.32478/evaluasi.v3i2.265

Menerapkan SNI 19-9001-2001." Jurnal Standardisasi 9, no. 3 (2007): 106-15.

Terry, George R. dan Rue, Leslie W. Dasar -Dasar Manajemen. Jakarta: Bumi Aksara, 2005.

Wahjosumidjo. Kepemimpinan Kepala Sekolah Tinjauan Teoritik Dan Permasalahannya. Jakarta: Raja Grafindo Persada, 2003. 